\title{
Biodistribution of the Radiopharmaceutical Technetium- 99m-Sodium Phytate in Rats After Splenectomy
}

\author{
Kércia Regina Santos Gomes Pereira ${ }^{1}$, Maria Kadja Meneses Torres Açucena ${ }^{1}$, Arthur \\ Villarim Neto ${ }^{1}$, Amália Cínthia Meneses Rêgo ${ }^{1}$, Mário Bernardo-Filho ${ }^{2}$, Ítalo Medeiros \\ Azevedo $^{3}$, Irami Araújo Filho ${ }^{3}$ and Aldo Cunha Medeiros ${ }^{3 *}$ \\ ${ }^{I}$ Centro de Ciências da Saúde; Universidade Federal do Rio Grande do Norte; Natal - RN - Brasil. ${ }^{2}$ Departamento \\ de Biofísica e Biometria; Instituto de Biologia Roberto Alcantara Gomes; Universidade do Estado do Rio de \\ Janeiro; Av. 28 de Setembro, 87; 20551030; Rio de Janeiro - RJ - Brasil. 3 Departamento de \\ Cirurgia;Universidade Federal do Rio Grande do Norte; Av. Nilo Peçanha, s/n; aldo@ufrnet.br; 59012300; Natal - \\ RN - Brasil
}

\begin{abstract}
Drugs and surgery can interfere with the biodistribution of radiopharmaceuticals and data about the effect of splenectomy on the metabolism of phytate-Tc-99m are scarce. This study aimed at evaluating the interference of splenectomy on phytate-Tc-99m biodistribution and liver function in rats. The SP group rats $(n=6)$ underwent splenectomy. In group $C$ (control) the animals were not operated on. After 15 days, all rats were injected with $0.1 \mathrm{~mL}$ of Tc-99m-phytate via orbital plexus $(0.66 \mathrm{MBq})$. After 30 minutes, liver samples were harvested, weighed and the percentage of radioactivity per gram (\%ATI/g) was determined by a Wizard Perkin-Elme gama counter. The ATI\%/g in splenectomized rats $(0.99 \pm 0.02)$ was significantly higher than in controls $(0.4 \pm 0.02),(p=0.034)$. $A L T, A S T$ and HDL were significantly lower in SP rats $(p=0.001)$ and leukocytosis was observed in SP rats. In conclusion, splenectomy in rats changed the hepatic biodistribution of Tc-99m-phytate and liver enzimatic activity.
\end{abstract}

Keywords: splenectomy, sodium phytate, biodistribution, liver

\section{INTRODUCTION}

The spleen is the largest lymphoid organ in the body. Its functions are many, but they are generally related to 1 of 4 categories: filtration, immunologic, reservoir, and hematopoietic. Many of the spleen's immunologic functions, therefore, are common to other immunologic organs. For example, the spleen is efficient at removing nonopsonized bacteria, mostly encapsulated organisms (Müftüoğlu et al., 2000). Splenectomy is frequently performed for a multitude of reasons, including trauma and various pathologic processes. Blunt abdominal trauma remains the most common indication for splenectomy, but patients with a variety of hematologic disorders also benefit from this procedure. Loss of the spleen, however, leads to a lifelong higher risk of sepsis and severe infection (Bader-Meunier et al., 2001, Waghorn et al., 1997) and may be associated with an increased rate of thromboembolic complications, enhanced arteriosclerosis, and late coronary heart disease (Schilling, 1997). It has been reported that splenectomy might promote hepatic regeneration, prevent liver fibrosis (Akahoshi et al., 2002, Murata et al., 2001), reduce

\footnotetext{
* Author for correspondence
} 
serum bilirubin concentration and improve liver function (Shimada et al., 2000, Lin et al., 1999). However, considering the relationship between the spleen and liver physiology, nuclear medicine may have an important role in studying the diagnosis and physiology of the liver after splenectomy.

Since its introduction a number of years ago, Tc99m-phytate colloid has been used as an imaging agent for the liver and spleen (Huet et al., 1980). Subjective assessment of parameters such as liver dimension, colloid shift, and radiopharmaceutical uptake in the bone marrow have been used for both liver disease diagnosis and evaluation of its progression. Subjective assessment of radiocolloid distribution has been shown to be unreliable, and quantitative techniques have been used to evaluate liver function (Jago et al., 1987). The distribution of radiocolloid uptake in the liver and bone marrow has been shown to correlate well with the severity of chronic liver disease, the severity of histologic fibrosis, prognosis, and hepatic function (Hoefs et al., 1997). Thus, quantitation of liver uptake of $99 \mathrm{mTc}$-phytate colloid provides a practical index of hepatic function, by using planar and single photon emission computed tomography (SPECT) techniques (Strauss et al., 1984). The ability to quantitate individual organ volumes and radiopharmaceutical concentrations with SPECT (Front et al., 1987, Iosilevsky et al., 1989) stimulates the use of $\mathrm{Tc}-99^{\mathrm{m}}$-phytate colloid scintigraphy of the liver as a quantitative test of hepatic function. Radiopharceutical biodistribution may provide important information about its uptake to some target organs but post -surgery data are scarce (Chacon et al., 2007, Araújo-Filho et al., 2007).

This study aimed at evaluating if splenectomy interferes with liver function and the biodistribution of $\mathrm{Tc}-99^{\mathrm{m}}$-fytate in the liver of Wistar rats.

\section{MATERIAL AND METHODS}

\author{
Animals \\ Male Wistar rats weighing $274 \pm 21$ g were obtained \\ from the Center for Health Sciences vivarium, \\ Universidade Federal do Rio Grande do Norte \\ (UFRN), Brazil. The animals were housed in \\ polypropylene cages and fed standard rat chow \\ and water ad libitum. Prior to surgery, the rats \\ were fasted overnight in separate cages. After 7 \\ days of acclimatization, they were allocated to two
}

groups of 6 animals each. The groups were denominated splenectomy (SP) and control (C). The protocol for this study was approved by the Institutional Animal Care Committee, and the research was performed in accordance with Brazilian College of Animal Experimentation guidelines

\section{Surgical procedure for splenectomy}

The rats were anesthetized with ketamine 50 $\mathrm{mg} / \mathrm{kg} \mathrm{IM}$ and thiopental $(20 \mathrm{mg} / \mathrm{kg} \mathrm{IP})$, shaved and placed on an operating board and secured with tape. Midline laparotomy $(3 \mathrm{~cm})$ was performed after skin sterilization with $70 \%$ ethanol. The animals were then covered with a small sterile drape with a $6 \mathrm{~cm}$ circular opening. In group SP $(n=6)$ the spleen was identified and resected after ligature of the splenic vessels with vicryl 5-0 (Ethicon, São Paulo, Brazil). The peritoneal cavity was irrigated with warm $\left(37^{\circ} \mathrm{C}\right)$ normal saline. The laparotomy wound was closed with 4-0 nylon in layers and individual rats were placed in separate cages. They were allowed water $a d$ libitum and rat chow $24 \mathrm{~h}$ postoperatively. The $\mathrm{C}$ rats $(n=6)$ were neither anesthetized nor operated on. Hydration was done with normal saline (10 $\mathrm{mL} / 100 \mathrm{~g}$ weight) injected subcutaneously in the back of the rats for the first two postoperative days. Postoperative pain was treated with tenoxicam (Roche Pharm., Brazil); $10 \mathrm{mg} / \mathrm{kg}$ was given i.m. to the rats once a day for three days.

\section{Body weight and clinical observation}

Body weight was monitored weekly throughout the entire 15-day experimental period. Activity, mucosa and skin color were observed daily.

\section{Radioactivity count}

Sodium pertechnetate $\left(\mathrm{Na}^{99 \mathrm{~m}} \mathrm{TcO}_{4}\right)$ was obtained by elution of a ${ }^{99} \mathrm{Mo} /{ }^{99 m} \mathrm{Tc}$ generator (Instituto de Pesquisas Energéticas e Nucleares, Comissão Nacional de Energia Nuclear, Brazil), and 99mTcphytate was prepared. On the 15th day all the animals were anesthetized again, and injected with $0.1 \mathrm{~mL}$ of $99 \mathrm{mTc}$-phytate in the orbital plexus, corresponding to radioactivity of $0.66 \mathrm{MBq}$. After 30 minutes, blood was collected by cardiac puncture for dosages and the animals were killed by lethal dose of anesthetic. Samples of the liver were harvested. The samples were washed in $0.9 \%$ saline, weighed on a high-precision digital scale (Bel-Mark 160-II Itáliaß) and subjected to radioactivity detection using a 1470 Wizard $^{\mathrm{TM}}$ 
Gamma Counter - Perkin-Elmer, Finland, with automatic correction of radiation decline. The percentage of radioactivity/g (\% ATI/g) of each organ was calculated by dividing the activity/g of the hepatic tissue by the total activity administered to each animal.

\section{Laboratory analysis}

A blood sample was used for hematological analysis of white blood cells (Abbot Cell Dyn 3500 automatic analyzer) and for the serum measure of alanine aminotransferase (ALT), aspartate aminotransferase (AST) and lactic desydrogenase activity, we used the Konelab 60i spectrophotometer (assay kit from Weiner, São Paulo, Brazil).

\section{Statistics}

The data were expressed as mean \pm standard deviation (SD). The groups were compared using ANOVA and the post-hoc Student test, considering a significance level of $\mathrm{p}<0.05$.

\section{RESULTS}

Postsplenectomy symptoms such as hematuria, pale mucosa and lethargy were observed in 3 animals but not in control rats. We observed no significant body weight loss in splenectomized rats, compared to controls. Radioactivity per gram of liver tissue $((\% \mathrm{ATI} / \mathrm{g})$ was increased by prior splenectomy in the SP group rats $(0.99 \pm 0.2)$, when compared to the control (C) group $(0.4 \pm 0.2)$. The difference between the two groups was significant $(\mathrm{p}=0.034$; Table 1$)$.

To examine the effects of prior splenectomy on liver function, we assessed the levels of ALT, AST and LDH activity, as a marker of liver injury, at 15 days postsplenectomy (Table 1). In splenectomized rats, ALT, AST and LDH values were markedly reduced, compared with the control group rats $(\mathrm{p}=0.001$; Table 1$)$. In addition, splenectomy resulted in increased white blood cell counts in the SP rats $(13.8 \pm 2.7 \mathrm{k} / \mu \mathrm{L})$, when compared to the $\mathrm{C}$ rats $(2.5 \pm 0.9 \mathrm{k} / \mu \mathrm{L}$; Table 1$)$.

Table 1 - Results of percentage of radioactivity per gram (\%ATI/g) of liver, hepatic enzyme activity and WBC count.

\begin{tabular}{lccc}
\hline Examinations & Splenectomy & Control & $\mathbf{p}^{(\mathbf{1})}$ \\
\hline Liver (\%ATI/g) & $0.99 \pm 0.2 \mathrm{~b}$ & $0.4 \pm 0.2$ & 0.034 \\
ALT (U/L) & $114.6 \pm 10.9$ & $157.5 \pm 13.2$ & 0.001 \\
AST (U/L) & $51.6 \pm 7.8$ & $62.0 \pm 2.5$ & 0.041 \\
LDH (mg/dL) & $8.2 \pm 2.4$ & $16.1 \pm 1.1$ & 0.001 \\
WBC (k/ $/ \mathrm{LL})$ & $13.8 \pm 2.7$ & $2.5 \pm 0.9$ & $<0.001$ \\
\hline
\end{tabular}

Mean \pm standard deviation; ALT, alanine aminotransferase; AST, aspartate aminotransferase; LDH, lactic dehydrogenase; pvalue from $t$ test for independent samples; WBC, white blood cells.

\section{DISCUSSION}

Based on current knowledge, there is no doubt that the spleen is a lymphoid organ. Filtration, immunology, reservoir, and hematopoiesis are such important functions, that partial splenectomy or the preservation of the organ by suture is indicated in cases of traumatic injuries (Resende and Petroianu, 2003). Various complications and beneficial effects of the operation are described in postoperative splenectomy (Cadili and Gara., 2008). Splenectomy might promote hepatic regeneration to a certain extent and prevent liver fibrosis (Murata et al., 2001, Chen et al., 1998).

In this study we demonstrated that in splenectomized rats the biodistribution of $99 \mathrm{mTc}-$ phytate to the liver was higher than in controls, suggesting that the operation favored the hepatic 
uptake of the radiopharmaceutical. This result coincided with the improvement in liver function, confirmed by the better alanine aminotransferase, aspartate aminotransferase and lactic dehydrogenase activities in splenectomized rats, compared with controls. In some studies splenectomy promoted hepatic regeneration (Akahoshi et al., 2002, Murata et al., 2001), prevented liver fibrosis (Chen et al., 1998), reduced serum bilirubin concentration and, consequently, reflected the effect of splenectomy on reducing the burden of hepatocyte bilirubin metabolism, improving liver function (Shimada et al, 2000, Lin et al., 1999).

Tomikawa et al (1996) reported that splenectomy increased hepatocyte growth factor (HGF) activities in plasma, suggesting that the spleen played an inhibitory role in hepatic regeneration. HGF, first identified as the most potent mitogen for primary hepatocytes, not only stimulates hepatic regeneration but also accelerates liver function. Moreover, the fact that a large amount of splenic tissue connects to liver tissue through the portal vein system, suggests the existence of a humoral factor originating in the spleen, which thus inhibits hepatic regeneration and promotes liver fibrosis. In rats submitted do hepatic ischemia/reperfusion, prior splenectomy ameliorated acute multiple organ damage (Jiang et al., 2007). These findings, associated to the favorable serum activity of ALT, AST and LDH in our splenectomized rats, partially explain the high hepatic biodistribution of $99 \mathrm{mTc}$-phytate in the operated animals.

The postsplenectomy diagnosis of sepsis based on elevated white blood cell (WBC) counts is confounded by the fact that leukocytosis is considered a physiologic response to splenectomy (Horowitz et al., 1992). Some reports suggest that postsplenectomy WBC counts in patients with sepsis are greater and more persistent than the WBC in patients without sepsis (Weng et al., 2005, Rutherford et al., 1994).

In this study we were not able to diagnose sepsis in the splenectomized rats. Nevertheless, all the operated animals had leukocytosis (WBC ranging from 11 to $18 \mathrm{k} / \mu \mathrm{L}$ ) in the $15^{\text {th }}$ postoperative day. It has been reported that by the fifth day following post-traumatic splenectomy, the WBC count may help the physician to confirm the development of sepsis and the need for treatment. If the WBC is greater than $15 \times 10^{3} / \mu \mathrm{L}$ on that day, the physician should seriously consider treatment by empiric antibiotics and further diagnostic follow-up to prevent the untoward sequelae of postsplenectomy sepsis (Toutouzas et al., 2002). In conclusion, splenectomy improved the liver uptake of Tc-99mphyate in rats, coinciding with changes in hepatic enzymatic activity.

\section{ACKNOWLEDEGMENT}

The authors thank Michael Germain, from Canada, for his help in revision of English language.

\section{RESUMO}

O radiofármaco fitato-Tc- $99 \mathrm{~m}$ é usado no diagnóstico através de exames de imagem, na dependência de sua biodistribuição. O objetivo do trabalho foi avaliar efeito da esplenectomia na biodistribuição do fitato-Tc-99m e função hepática em ratos Wistar. Sob anestesia e técnica asséptica, os animais do grupo SP $(n=6)$ foram esplenectomizados. Grupo $\mathrm{C}($ controle; $\mathrm{n}=6)$ não operado. Após 15 dias, injeção de $0,1 \mathrm{ml}$ de fitatoTc-99m via plexo orbital $(0,66 \mathrm{MBq})$. Após 30 minutos, retiradas biópsias hepáticas para determinação do percentual de radioatividade/grama (\% ATI/g), usando-se contador gama WizardPerkin-Elmer ${ }^{\circledR}$. Realizada dosagem de ALT, AST e HDL, e leucometria. Estatística pelo teste $\mathrm{t}$, significância 0,05. O $\% \mathrm{ATI} / \mathrm{g}$ nos ratos esplenectomizados foi $0,99 \pm$ 0,2 e nos controles $0,40 \pm 0,2(p=0,034)$. ALT, AST e HDL tiveram dosagens significativamente menores nos esplenectomizados $(\mathrm{p}=0,01)$, com leucocitose, comparando com controles. Em conclusão, em ratos a esplenectomia provocou alteração na captação de fitato-Tc-99m pelo fígado, coincidindo com alteração da função hepática.

Palavras-Chave: esplenectomia, fitato de sódio, biodistribuição, fígado

\section{REFERENCES}

Akahoshi, T.; Hashizume, M.; Tanoue, K. et al. (2002), Role of the spleen in liver fibrosis in rats may be mediated by transforming growth factor beta-1. $J$ Gastroenterol Hepatol., 17, 59-65.

Araújo-Filho, I.; Rego, A. C. M.; Brandao-Neto, J.; Villarim-Neto A.; Egito E. S. T.; Azevedo I. M.; 
Medeiros A. C. (2007), Biodistribution of the radiopharmaceutical sodium pertechnetate after biliopancreatic bypass with a duodenal switch. Braz Arch Biol Technol., 50, 189-197.

Bader-Meunier, B.; Gauthier, F.; Archambaud, F. (2001), Long-term evaluation of the beneficial effect of subtotal splenectomy for management of hereditary spherocytosis. Blood, 97, 399-403.

Cadili, A.; Gara, C. (2008), Complications of splenectomy. Am J Med., 121, 371-375.

Chacon, D. A.; Araújo-Filho, I.; Villarim-Neto, A.; Rêgo, A. C.; Azevedo, I. M.; Bernardo-Filho, M.; Brandão-Neto, J.; Medeiros, A. C. (2007), Biodistribution of the radiophamarceutical sodium pertechnetate $\left(\mathrm{Na}^{99 \mathrm{~m}} \mathrm{TcO}_{4}\right)$ after massive small bowel resection in rats. Acta Cir Bras., 22, 430-435.

Chen, D.; Liu, W.; Leng, E.; Wu, B. (1998), Effect of splenectomy on CCl4-induced liver fibrosis in rats. Chin Med J., 111, 779-783.

Front, D.; Ioselevsky, G; Frenkel, A . (1987), In vivo quantitation using SPECT of radiopharmaceutical uptake by human meningiomas. Radiology, 164, 9396.

Hoefs, J. C.; Wang, F.; Kanel, G. (1997), Functional measurement of nonfibrotic hepatic mass in cirrhotic patients. Am J Gastroenterol., 92, 2054-2058.

Horowitz, J.; Leonard, D.; Smith, J.; Brotman, S. (1992), Postsplenectomy leukocytosis: physiologic or an indicator of infection? Am Surg., 58, 387-390.

Huet, P. M.; Chartrand, R.; Marleau, D. (1980), Extrahepatic uptake of Tc-99m-phytate: its mechanism and significance in chronic liver disease. Gastroenterology, 78, 76-80.

Iosilevsky, G.; Israel, O.; Frenkel, A. (1989), A practical SPECT technique for quantitation of drug delivery to human tumors and organ absorbed radiation dose. Semin Nucl Med., 19, 33-46.

Jago, J. R.; Gibson, C. J.; Diffey, B. L. (1987), Evaluation of subjective assessment of liver function from radionuclide investigations. $B r J$ Radiol., 60, 127-132

Jiang, H.; Meng, F. Li, W.; Tong, L.; Qiao, H.; Sun, X. (2007), Splenectomy ameliorates acute multiple organ damage induced by liver warm ischemia reperfusion in rats. Surgery, 141, 32-40.

Lin, M. C.; Wu, C. C.; Ho, W. L.; Yeh, D. C.; Liu, T. J.; Peng, F. K. (1999), Concomitant splenectomy for hypersplenic thrombocytopenia in hepatic resection for hepatocellular carcinoma. Hepatogastroenterology, 46, 630-634.

Müftüioğlu, T. M.; Köksal, N.; Ozkutlu, D. (2000), Evaluation of phagocytic function of macrophages in rats after partial splenectomy. J Am Coll Surg., 191, 668-671.
Murata, K.; Shiraki, K.; Sugimoto, K. (2001), Splenectomy enhances liver regeneration through tumor necrosis factor (TNF)-alpha following dimethylnitrosamine-induced cirrhotic rat model. Hepatogastroenterology, 48, 1022-1027.

Resende, V.; Petroianu, A. (2003), Functions of the splenic remnant after subtotal splenectomy for treatment of severe splenic injuries. Am J Surg., 185, 311-315.

Rutherford, E. J.; Morris, J. A. Jr; van Aalst, J.; Hall, K. S.; Reed, G. W.; Koestner, J. A. (1994), The white blood cell response to splenectomy and bacteraemia. Injury, 25, 289-292.

Schilling, R. F. (1997), Spherocytosis, splenectomy, strokes, and heart attacks. Lancet., 350, 1677-1678 .

Shimada, M.; Hashizume, M.; Shirabe, K.; Takenaka, K.; Sugimachi, K. (2000), A new surgical strategy for cirrhotic patients with hepatocellular carcinoma and hypersplenism. Performing a hepatectomy after a laparoscopic splenectomy. Surg Endosc., 14, 127130.

Strauss, L. G.; Clorius, J. H.; Frank, T.; Van Kaick, G. (1984), Single photon emission computerized tomography (SPECT) for estimates of liver and spleen volume. J Nucl Med., 25, 81-85.

Tomikawa, M.; Hashizume, M.; Highashi, H. (1996), The role of the spleen, platelets, and plasma hepatocyte growth factor activity on hepatic regeneration in rats. J Am Coll Surg., 182, 12-16.

Toutouzas, K. G.; Velmahos, G. C.; Kaminsk, A.; Chan, L.; Demetriades, D. (2002), Leukocytosis After Posttraumatic Splenectomy. A Physiologic Event or Sign of Sepsis? Arch Surg., 137, 924-929.

Waghorn, D. J.; Mayon-White, R. T. (1997), A study of 42 episodes of overwhelming post- splenectomy infection: is current guidance for asplenic individuals being followed? J Infect., 35, 289 -294.

Weng, J.; Brown, C. V.; Rhee, P.; Salim, A.; Chan, L.; Demetriades, D.; Velmahos, G. C. (2005), White blood cell and platelet counts can be used to differentiate between infection and the normal response after splenectomy for trauma: prospective validation. J Trauma, 59, 1076-80.
Received: August 18, 2008; Revised: September 16, 2008; Accepted: September 18, 2008 